\title{
Aspecte clinice şi genetice în cadrul sindromului Ehlers Danlos
}

\author{
Elena Silvia Shelby', Mădălina Cristina Leanca', Șerban Hamei², \\ Liliana Pădure ${ }^{1,3}$, Andrada Mirea ${ }^{1,3}$ \\ ${ }^{1}$ Centrul Național Clinic de Recuperare Neuropsihomotorie \\ „Dr. Nicolae Robănescu“, București, România \\ 2Spitalul Clinic de Copii „Marie Skodlowska Curie“, Bucureşti, România \\ 3Universitatea de Medicină şi Farmacie „Carol Davila“, București, România
}

\begin{abstract}
REZUMAT
Introducere. Sindromul Ehlers Danlos reprezintă un grup de boli ereditare ale țesutului conjunctiv, cu o prevalență combinată de 1 la 5.000 de cazuri ce au în comun hiperlaxitate articulară și anomalii ale pielii. În unele tipuri, diagnosticarea rapidă poate însemna salvarea vieții pacientului.

Prezentare de caz. Vom prezenta cazul unei fetițe în vârstă de doi ani care este adusă pentru consult genetic cu suspiciunea de sindrom Ehlers Danlos. Pacienta prezenta hiperextensibilitate articulară și tegumentară, piele catifelată cu tendință la echimoze, luxație congenitală de șold cu o intervenție chirurgicală eșuată, talus varus și retard sever de dezvoltare motorie. Testarea genetică a evidențiat substituția c.1780C>T, p.(Arg594*) în gena COL5A1 ce duce la apariția unui codon stop prematur, mutația fiind de clasă 2 (potențial patogenică).

Concluzii. Până în prezent, această variantă a mai fost raportată în literatură la doar doi pacienți, acesta fiind al treilea. Toate cele trei cazuri corespund sindromului Ehlers Danlos tip clasic.
\end{abstract}

Cuvinte cheie: sindromul Ehlers Danlos, hiperlaxitate articulară, COL5A1

\section{INTRODUCERE}

Sindromul Ehlers Danlos reprezintă un grup de boli ereditare ale țesutului conjunctiv (1) cu o prevalență combinată (pentru toate tipurile) de 1 la 5.000 de cazuri (2). Sunt afectate articulațiile, pielea, vasele de sânge sau alte organe (2).

Conform clasificării facute de Beighton și colaboratorii săi în 1998 (Nosologia Villefranche) (3), sindromul Ehlers Danlos a fost împărțit în șase tipuri majore ce au în comun hiperlaxitate articulară și anomalii ale pielii, prezintă frecvent dilatație de aortă și, rar, ruptură de aortă (de exemplu, în tipul vascular) (1). În 2017, Malfait și colaboratorii (4) au revizuit criteriile de clasificare conform bazei moleculare responsabile de etiologie, împărțind sindromul Ehlers Danlos în 14 subtipuri (5), dintre care la ora actuală este cunoscut mecanismul molecular de producere pentru 13 dintre ele (6).
Caracteristicile comune prezente în toate tipurile de sindrom Ehlers Danlos sunt hiperlaxitatea articulară și anomaliile epiteliale (1). Hipermobilitatea este evaluată, pentru toate tipurile, utilizând scala Beighton, pe baza căreia, în funcție de gradul de mobilitate a unor anumite articulații, este realizat un scor diagnostic; dacă acesta este mai mare sau egal cu $5 / 9$, se consideră ca pacientul prezintă hipermobilitate $(1,7)$.

Conform criteriilor internaționale de diagnostic stabilite în 2017, sindromul Ehlers Danlos se împarte în subtipurile: clasic, vascular, cu atrocalazie, cu dermatosparaxis, cardiac-valvular (produse prin tulburări ale structurii primare și procesării colagenului), cifoscoliotic (produs prin tulburări ale împachetării și polimerizării colagenului), classic-like și miopatic (produse prin tulburări ale structurii și funcției miomatrixului - membrana bazală a mușchiului scheletic) $(5,8,9)$, spondilodisplazic și musculocontractural 
(produse prin disfuncții ale biosintezei glicozaminoglicanilor), parodontal (produs prin disfuncții ale căii complementului), spondilodisplazic SLC39A13 și sindromul corneei fragile (produse prin disfuncții ale procesării intracelulare), precum și hipermobil (la care mecanismul de producere a bolii nu a fost încă elucidat) $(5,8)$.

Colagenul este o proteină fibrilară prezentă în structura țesutului conjunctiv uman, îndeosebi la nivelul articulațiilor, al pielii și al oaselor $(10,11)$, fiind cea mai abundentă proteină a matricei extracelulare $(10,12)$ și, totodată, cea mai abundentă proteină din organism, unde are un rol esențial în menținerea structurii și stabilității diferitelor organe (13). Până la ora actuală, sunt cunoscute 28 de tipuri de colagen $(13,14)$, cel mai comun fiind tipul I, ce reprezintă peste $90 \%$ din totalul colagenului ce intră în componența corpului uman (14). Principalele componente ale colagenului sunt glicina, prolina și hidroxiprolina, formând 3 lanțuri împachetate sub forma unui triplu helix $(14,15)$.

Colagenul de tip $\mathrm{V}$ este sintetizat în diverse tipuri de celule mezenchimale sub influența TGF- $\beta$ și a altor factori de creștere și degradat de către metaloproteinaze şi gelatinaze, enzime cu rol în remodelarea matricei extracelulare (16). Acest tip de colagen este întâlnit la nivelul țesuturilor ce conțin colagen de tip I, unde are rol în reglarea procesului de împachetare a fibrelor heterotipice compuse din colagen de tip I și colagen de tip V (17). Astfel, colagenul de tip $\mathrm{V}$ intră în componența stromei corneale, a matricei osoase și a stromei ficatului, plămânilor, mușchilor și placentei (18). Absența colagenului de tip V a fost asociată cu tipul clasic de sindrom Ehlers Danlos, precum şi cu pierderea transparenței corneene, în timp ce supraexpresia acestei molecule este asociată cu procese patologice ca fibroză, cancer, inflamație sau ateroscleroză (16).

Sindromul Ehlers Danlos de tip clasic este cauzat în principal de mutații autozomal dominante în genele COL5A1 și COL5A2 şi, în cazuri mai rare, COL1A1 $(19,20)$ și are drept criterii majore de diagnostic hiperextensibilitatea articulară generalizată și hiperextensibilitatea tegumentară cu cicatrice atrofice (19), printre criteriile minore numărându-se pielea catifelată, fragilitatea și extensibilitatea tisulară, ce pot duce la complicații ca prolaps anal, hernie hiatală, incompetență cervicală, prezența sferoidelor subcutanate (formațiuni parțial calcificate ce apar la nivelul proeminențelor osoase), pseudotumorilor moluscoide (cicatrici tegumentare apărute la nivelul zonelor supuse frecvent la presiune, precum coate sau genunchi), predispoziție la echimoze, hipotonie musculară, întârziere în obținerea achizițiilor motorii, precum și complicații ale hiperextensibilității ar- ticulare ca dislocații de umăr, șold, patelă, claviculă sau radius $(20,21)$. La nivel global, tipul clasic de sindrom Ehlers Danlos are o prevalență de 1 la 20.000 (22).

\section{PREZENTAREA CAZULUI}

O fetiță în vârstă de doi ani a fost adusă pentru consult genetic cu suspiciunea de sindrom Ehlers Danlos. Istoricul familial și antecedentele personale fiziologice au fost nesemnificative.

Din punctul de vedere al istoricului medical, pacienta s-a născut cu luxație congenitală de șold unilaterală, pentru care s-a intervenit chirurgical la vârsta de 1 an și 4 luni. Totuși, a fost necesară o a doua intervenție chirurgicală, la 1 an și 7 luni.

Pacienta a prezentat retard în obținerea achizițiilor motorii pe etape - și-a putut susţine singură gâtul la 4 luni și jumătate, a putut sta în șezut la 9 luni și, la momentul consultului, mersul nu fusese achiziționat, însă putea menține ortostatismul. Cognitiv, pacienta era în limitele normalului.

Aparținătorii au afirmat că pacienta nu are predispoziție la echimoze și că nu a prezentat vreodată epistaxis sau pneumotorax.

În momentul consultului, pacienta nu efectuase niciodată o ecografie de cord, iar nivelurile creatinkinazelor serice nu fuseseră niciodată evaluate.

La examenul clinic, parametrii creșterii erau normali. Pacienta prezenta un ușor dismorfism facial cu hipertelorism şi micrognaţie. Pacienta avea hiperextensibilitate articulară (6/9 puncte pe scala Beighton), piele catifelată, păstoasă și hiperextensibilă, o ușoară asimetrie de membre, cicatrice postoperatorie de tip atrofic la nivelul șoldului drept și talus varus bilateral.

Pentru elucidarea cauzei, o probă de sânge $(2 \mathrm{ml}$ pe EDTA) a fost recoltată pentru secvenţiere de noua generație- panel țintit de gene responsabile de sindromul Ehlers Danlos. A fost identificată substituția c. $1780 \mathrm{C}>\mathrm{T}$, p. $\left(\operatorname{Arg} 594^{*}\right)$ în gena COL5A1 în stare heterozigotă. Această substituție este considerată o mutaţie de clasa a doua - probabil patogenică - şi duce la apariția unui codon stop prematur. Mutații în această genă au fost asociate cu sindromul Ehlers Danlos tip clasic cu transmitere autozomal dominantă. Până în prezent, această variantă a mai fost raportată în literatură la doar doi pacienți, acesta fiind al treilea. Toate cele trei cazuri corespund sindromului Ehlers Danlos tip clasic.

\section{DISCUȚII}

La ora actuală, în baza de date ClinVar sunt cunoscute peste 100 de mutații patogenice sau potențial 
patogenice în gena COL5A1, dintre care 16 sunt missense (23).

Varianta identificată de noi, c.1780 C>T, p.(Arg594*) în gena COL5A1, duce la apariția unui codon stop prematur și la pierderea funcției proteinei prin apariția unei proteine trunchiate, cu codificarea a numai 593 din 1.837 de aminoacizi. Până la ora actuală, varianta a fost raportată numai la alți doi pacienți (24), fiind raportată și în baza de date ClinVar (25). Varianta este absentă din baza de date Genome Aggregation Database (gnomAD) (26).

Astfel, singurul alt studiu din literatură în care este raportată această variantă a fost efectuat de Malfait și colaboratorii săi în 2005 (24), asupra a 48 de pacienți neînrudiți diagnosticați clinic, pe baza criteriilor definite de Nosologia Villefranche în 1997, cu tipul clasic de sindrom Ehlers Danlos, criteriile de includere fiind hiperextensibilitatea articulară, prezența cicatricilor atrofice extinse și a hipermobilității articulare generalizate. Malfait și colaboratorii săi au analizat prezența defectelor în structura colagenului de tip I și V în culturi de fibroblaşti prelevate de la acești pacienți utilizând diferite metode, ca analiza fluorografică a colagenului de tip V marcat cu radioizotopi pentru identificarea alelelor nule, nefuncționale, de colagen $\mathrm{V}$, electroforeza genelor COL1A1, COL1A2, COL5A1 și COL5A2 utilizând metodele SSCP (single-strand conformation polymorphism) şi CSGE (conformation sensitive gel electrophoresis) pentru identificarea anomaliilor de migrare și, deci, a mutațiilor la nivelul acestor gene, studii de înlănțuire asupra mutațiilor genei COL5A1 utilizând microsateliți intragenici și extragenici folosind ADN sau ADN complementar obținut prin reverstranscripția ARN pentru a analiza modul de segregare a variantelor în familiile pacienților, amplificarea și secvențierea de ADN pentru identificarea anumitor mutaţii la nivelul colagenului $\mathrm{V}$ și colagenului I, precum şi analiza a trei situsuri polimorfice la nivelul ADN complementar al genei COL5A1 pentru identificarea polimorfismelor de la acest nivel.

Dintre cei 48 de pacienți, la 18 (reprezentând $37,5 \%$ ) a fost identificată o alelă nefuncțională a colagenului V. În ciuda identificării unui codon stop prematur la majoritatea pacienților, expresia alelei COL5A1 nule nu era în totalitate absentă.

Mutaţia identificată de noi, c.1780C $>\mathrm{T}$, p.(Arg594*) în gena COL5A1, este prezentă la pacienții EDS15 și EDS20 ai studiului efectuat de Malfait (p.R594X). Mutația afectează codonul 16 al genei COL5A1, substituția ducând la apariția unui codon stop prematur. Interesant, studiile iniţiale utilizând electroforeza genei COL5A1 prin SSCP şi CSGE nu au identificat anomalii de migrare la pacienta EDS15, mutațiile prezente la aceasta pacientă fiind identificate ulterior folosind dHPLC (denaturing high performance chromatography - cromatografie de înaltă performanță în stare lichidă). Asemenea pacientei identificate de noi, și cei doi pacienți cu mutaţia c.1780C > T, p.(Arg594*) în gena COL5A1, respectiv EDS15 și EDS20 din studiul lui Malfait sunt de sex feminin. Pacienta EDS15 avea, la momentul studiului, 11 ani, iar pacienta EDS20, 19 ani. Pacienta EDS15 prezenta o mutație spontană, în timp ce la pacienta EDS20 mutația era moștenită (modul de transmitere fiind autozomal dominant). Deoarece părinţii pacientei noastre nu doresc încă testarea, nu putem ști cu exactitate modul de segregare al variantei, totuși, pe baza anamnezei, putem presupune că mutaţia este de novo, antecedentele heredocolaterale fiind nesemnificative.

Cazul prezentat de noi are în comun cu pacientele EDS15 și EDS20 hiperextensibilitatea articulară și prezența pielii moi, catifelate (pacienta având, la momentul studiului, doi ani) şi relativ hiperextensibile (pielea putând fi extinsă cu aproximativ $1,5 \mathrm{~cm}$ la nivelul porțiunii distale a antebrațelor și la nivelul porțiunii dorsale a mâinilor), precum și a cicatricilor atrofice (pacienta prezentând o cicatrice atrofică postoperatorie la nivelul șoldului drept). Spre deosebire de pacientele EDS15 și EDS20 descrise de Malfait, ce prezentau tendință la echimoze, conform anamnezei și examenului clinic, pacienta examinată de noi nu prezenta această predispoziție. Trebuie însă inclus în context și faptul că, la momentul analizei, ea nu achiziționase încă mersul.

În studiul efectuat de Malfait, pacienta EDS15 prezintă și prolaps anal, caracteristică neîntâlnită la pacienta noastră și nici la pacienta EDS 20. În afară de aceste caracteristici, pacientele EDS15 și EDS20 nu prezentau alte trăsături clinice relevante (ca, de exemplu, statură joasă, sclere albastre, dizlocații recurente sau luxații de șold sau umăr). Pacienta noastră prezenta un ușor dismorfism facial cu hipertelorism și micrognaţie, luxație congenitală de șold unilaterală și talus varus bilateral.

\section{CONCLUZII}

Din punct de vedere fenotipic, pacienta prezintă trăsături ale sindromului Ehlers Danlos de tip clasic, testarea genetică confirmând prezența acest sindrom.

Studiul de față este important pentru practica pediatrică întrucât varianta este foarte rară, până în prezent ea fiind raportată în literatură la numai doi pacienți, cazul prezentat de noi fiind al treilea. Toți cei trei pacienți sunt de sex feminin.

Deoarece datele prezentate până la ora actuală în singurul studiu ce descrie pacienți cu această mutație sunt foarte sumare, și deoarece pacienta noastră pre- 
zintă trăsături fenotipice adiţionale celor prezentate până acum (ușor dismorfism facial cu hipertelorism și micrognaţie, luxație congenitală de șold unilaterală și talus varus bilateral), considerăm că prezentarea detaliată acestui caz poate fi utilă în extinderea cunoștințelor despre tipul clasic de sindrom EhlersDanlos și despre această variantă.

\section{BIBLIOGRAFIE}

1. Tinkle BT, Atzinger CL. Ehlers-Danlos Syndrome. In: Cassdy S, Allanson J. Management of Genetic Syndromes. New Jersey: Wiley Blackwell. Third Edition. 2010: 337-361.

2. Genetics Home Reference. [Online]. [Updated 2020]. Available from: URL: https://ghr.nlm.nih.gov/condition/ehlers-danlossyndrome\#statistics.

3. Beighton P, De Paepe A, Steinmann B, Tsipouras P, Wenstrup RJ. Ehlers-Danlos syndromes: revised nosology, Villefranche, 1997. Ehlers-Danlos National Foundation (USA) and Ehlers-Danlos Support Group (UK). Am J Med Genet. 1998;77(1):31-7.

4. Malfait F, Francomano C, Byers P, Belmont J, Berglund B, Black J, Bloom L, Bowen JM, Brady AF, Burrows NP, Castori M, Cohen H, Colombi M, Demirdas S, De Backer J, De Paepe A, Fournel-Gigleux S, Frank M, Ghali N, Giunta C, Grahame R, Hakim A, Jeunemaitre X, Johnson D, Juul-Kristensen B, Kapferer-Seebacher I, Kazkaz H, Kosho T, Lavallee ME, Levy H, Mendoza-Londono R, Pepin M, Pope FM, Reinstein E, Robert L, Rohrbach M, Sanders L, Sobey GJ, Van Damme T, Vandersteen A, van Mourik C, Voermans N, Wheeldon N, Zschocke J, Tinkle B. The 2017 international classification of the Ehlers-Danlos syndromes. Am J Med Genet C Semin Med Genet. 2017;175(1):8-26.

5. The Ehlers-Danlos Society. EDS Types. [Online]. [2020]. Available from: URL: https://www.ehlers-danlos.com/eds-types/.

6. Malfait F, Castori M, Francomano CA, Giunta C, Kosho T, Byers PH. The Ehlers-Danlos syndromes. Nat Rev Dis Primers. 2020;6:63.

7. Benign Joint Hypermobility Syndrome - not just a flexible child. Children's Podiatry Melbourne. [Online]. [2016]. Available from: URL: http://childrenspodiatry.melbourne/index.php/blog/benign-jointhypermobility-syndrome-not-just-flexible-child.

8. Meester JAN, Verstraeten A, Schepers D, Alaerts M, Van Baer L, Loeys BL. Differences in manifestations of Marfan syndrome, Ehlers-Danlos syndrome, and Loeys-Dietz syndrome. Annals of Cardiothoracic Surgery. 2017;6(6):582-594.

9. Ruegg MA, Meinen S, Maier G, Lin S, Yurcencho PG. The role of laminins in myomatrix assembly and skeletal muscle stability. Neuromuscular Disorders. 2013;23(9-10):738-739.

10. Chiarelli N, Ritelli M, Zoppi N, Colombi M. Cellular and Molecular Mechanisms in the Pathogenesis of Classical, Vascular, and Hypermobile Ehlers-Danlos Syndromes. Genes (Basel). 2019; 10(8):609.

11. Avila Rodriguez MI, Rodriguez Barroso LG, Sanchez ML. Collagen: A review on its sources and potential cosmetic applications. Journal of Cosmetic Dermatology. 2017;17.

12. Sorushanova A., Delgado LM, Wu Z, Shologu N, Kshirsagar A, Raghunath R, Mullen AM, Bayon Y, Pandit A, Raghunath M, Zeugolis DI. The Collagen Superfamily: From Biosynthesis to Advanced Biomaterial Development. Adv Mater. 2019;31(1).

\section{Notă}

Autorii doresc să mulțumească aparținătorilor pacientei pentru buna colaborare.

\section{Conflict of interest: none declared} Financial support: none declared
13. Kwatra B. Collagen Supplementation: Therapy for Skin Disorders: A Review. World Journal of Pharmaceutical Research. 2020; 9(5):2504-2518.

14. Wu M, Cronin K, Crane JS. Biochemistry, Collagen Synthesis. [Updated 2020 Sep 11]. In: StatPearls [Internet]. Treasure Island (FL): StatPearls Publishing; 2020 Jan-. Available from: https://www. ncbi.nlm.nih.gov/books/NBK507709/.

15. León-López A, Morales-Peñaloza A, Martínez-Juárez VM, VargasTorres A, Zeugolis DI, Aguirre-Álvarez G. Hydrolyzed CollagenSources and Applications. Molecules. 2019;24(22):4031.

16. Mak KM, Png CY, Lee DJ. Type V Collagen in Health, Disease, and Fibrosis. Anat Rec (Hoboken). 2016;299(5):613-29.

17. COL5A1 - collagen type $V$ alpha 1 chain. NCBI Gene. [Online]. [Updated 2020]. Available from: URL: https://www.ncbi.nlm.nih.gov/ gene?Db=gene\&Cmd=DetailsSearch\&Term=1289.

18. DJ Leeming, MA Karsdal. Type V Collagen. In: Karsdal MA. Biochemistry of Collagens, Laminin and Elastin. Second Edition. Elsevier Inc. 2019:51-57.

19. Ritelli M, Venturini M, Cinquina V, Chiarelli N, Colombi M. Multisystemic manifestations in a cohort of 75 classical EhlersDanlos syndrome patients: natural history and nosological perspectives. Orphanet J Rare Dis. 2020;15(1):197.

20. Malfait F, Wenstrup R, De Paepe A. Classic Ehlers-Danlos Syndrome. 2007 [Updated 2018]. In: Adam MP, Ardinger HH, Pagon RA, et al., editors. GeneReviews ${ }^{\circledR}$ [Internet]. Seattle (WA): University of Washington, Seattle; 1993-2020. Available from: https://www.ncbi. nlm.nih.gov/books/NBK1244/.

21. Malfait F, Wenstrup RJ, De Paepe A. Clinical and genetic aspects of Ehlers-Danlos syndrome, classic type. Genet Med. 2010 Oct; 12(10):597-605.

22. Classical Ehlers-Danlos syndrome. Orphanet. [Online]. [Updated 2020]. Available from: URL: https://www.orpha.net/consor/cgi-bin/ OC_Exp.php?lng=en\&Expert=287.

23. COL5A1. ClinVar. [Online]. [Updated 2020]. Available from: URL: https://www.ncbi.nlm.nih.gov/clinvar/?term=COL5A1\%5Bgene\%5D.

24. Malfait F, Coucke P, Symoens S, Loeys B, Nuytinck L, De Paepe A. The molecular basis of classic Ehlers-Danlos syndrome: a comprehensive study of biochemical and molecular findings in 48 unrelated patients. Hum Mutat. 2005 Jan;25(1):28-37.

25. NM_001278074.1 (COL5A1): c.1780C>T (p.Arg594Ter). [Online]. [Updated 2020]. Available from: URL: https://www.ncbi.nlm.nih.gov/ clinvar/variation/519624/.

26. COL5A1. gnomAD browser. [Online]. [Updated 2020]. Available from: URL: https://gnomad.broadinstitute.org/gene/ ENSG00000130635?dataset=gnomad_r2_1. 